\title{
What Factors Decide the Willingness of Higher Vocational College Students to Run a Company: An Empirical Study of the Impact of Willingness to Start Business
}

\author{
Zhaojie Cao ${ }^{1,}$, , Lanxi Wang ${ }^{2}$ \\ ${ }^{1}$ School of Education and Psychological Science, Sichuan University of Sciences \& Engineering, Zigong, China \\ ${ }^{2}$ College of Management, Sichuan Agricultural University, Wenjiang, China
}

Email address:

zjcao@suse.edu.cn (Zhaojie Cao)

${ }^{*}$ Corresponding author

To cite this article:

Zhaojie Cao, Lanxi Wang. What Factors Decide the Willingness of Higher Vocational College Students to Run a Company: An Empirical Study of the Impact of Willingness to Start Business. International Journal of Education, Culture and Society. Vol. 5, No. 5, 2020 , pp. 85-94. doi: $10.11648 /$ j.ijecs.20200505.11

Received: August 14, 2020; Accepted: September 3, 2020; Published: September 21, 2020

\begin{abstract}
Under the pressure of the global economic downturn and shrinking international market, especially the challenges from the COVID-19 pandemic, higher vocational college students in China have encountered a big problem in finding job. Therefore, efforts should be made to improve the employment environment by promoting students' entrepreneurship interest. Higher vocational colleges as the cradle of talent cultivation, should not only serve as a source of high-lever technology talents to support the country's high-quality development, but also provide students with knowledge, skills and motivation to encourage students to create entrepreneur in a variety way. This experimental study explored factors that influence higher vocational college students' entrepreneurial situation perceptions. Using data collected from 313 higher vocational college students and 100 of their parents, 100 teachers and 20 governors. We examined the impact of students' attitude, self-quality and individual interest to start a business. Besides, government policy and family support were also considered to evaluate the influence of their decision by external support. The results suggest that not only students' attitude and self-quality but also individual interest have impacts on individuals' willingness to start a business. The influence of family support was greater than government policy. The government policy has no significant influence on students' willing to start a business.
\end{abstract}

Keywords: Entrepreneur Willingness, Higher Vocational College Students, Family Support, Government Policy

\section{Introduction}

Employment among higher vocational college students in China has always been a big challenge. The issue of unemployment among young people is prevalent in the time of COVID-19 pandemic. Since the start of the outbreak of virus, many factories had to stop their production during the time of controlling and treating affected people. As the number of epidemic-affected people increased in many countries, many oversea-companies had cancelled the orders to China and this led to the serious unemployment [1]. Higher vocational colleges, as the main units to provide high quality talents towards the society, should shoulder the mission of cultivating more useful technical personnel. Therefore, higher vocational colleges should carry out researches on training excellent talents with entrepreneurship. An analysis of the willingness of entrepreneurship assists the learning of real situation of higher vocational college students' employment competitiveness. It also helps to strengthen the students' occupational qualities to start a business.

This study was to examine the factors which states that entrepreneurial willingness involves self-qualification, such as attitude, ambition, courage, interest, experiences as well as family support and government policies etc. And then it introduces analysis about different factors that would influence the entrepreneurial intentions and generated impact on entrepreneurial activities of higher vocational college students. In addition, this article discusses the most common approaches to train higher vocational college students' entrepreneurship qualities; all these are based on the real 
situation of students' current entrepreneurship willingness [2]

\section{Significance on Cultivating Higher Vocational College Students' Entrepreneurship Willingness}

The significance on cultivating higher vocational college students' entrepreneurship willingness embodies in three aspects. Firstly, Through investigating students' willingness, we can learn their real thoughts of setting up a new business so that we can offer them correct guidance for starting a new career. It can also encourage vocational college students to make strong determination for founding of small and medium enterprises if we can give them an effective entrepreneurship education. Many successful stories show that individuals with strong willingness to start a business would have become successful entrepreneurs or business owners in the future [3]. Therefore, the entrepreneurship education has a real impact on the success of start-ups and business owners. Secondly, willingness of entrepreneurship is regarded as an important motivation that can influence the emergence of entrepreneurial behavior in the future [4]. Cultivating students' willingness can increase vocational college students' motivation to be entrepreneurs. This education plays a significant role in motivating people to set a company or run an enterprise. One study found that developing entrepreneurial competence for vocational college students will give them more confidence in entrepreneurial mindset [5]. Cultivating entrepreneurial skills of vocational college students may also give students a greater sense of starting multiple ventures. As we all know, becoming a successful business owner is a long arduous process. Training higher vocational college students' entrepreneurship willingness can not only help them realize their dreams to get into business, but also help them improve their entrepreneurial qualities so that they can qualify for every profession. Thirdly, the willingness of entrepreneurship represents an individual's commitment to start a business. Individuals with entrepreneurial willingness believe that they can launch a new business successfully [6]. Thus cultivating students' willingness can relieve the employment pressure of vocational college students. For a vocational education student with a strong entrepreneurial willingness can help to alleviate the employment pressure of the society. They can hire more students in their factories to solve the problem of students' employment difficulty.

\section{Research Design}

\subsection{Problem Statement}

Due to the cut-throat competition, the prevalent trend for jobseekers, especially for vocational college graduates, has become more difficult in recent time. The specific problem of employment was somebody who fails in finding a job needs to change his situation in order to make a living, hence they have to seek for another way to earn the money and to do their own business is a better choice for them. But there was a lack of research into the willingness of vocational college students for a start-up. Therefore, researchers want to find out a better way to foster the entrepreneurial mind of higher college students which need to master the current true circumstances of students' entrepreneurship intention.

This study believes that the entrepreneurial intention of higher vocational college students is not entirely voluntary; it's controlled by a variety of external factors. Through literature analysis and questionnaire survey, we can attribute the influence of entrepreneurial behavior would contain attitude toward entrepreneur, government policies and family support. The findings hold that the behavior attitude, family support and perceived behavior control of higher vocational college students have significant positive effects on entrepreneurial willingness [7]. According to this, the following research assumptions can be put forward:

H1: The behavior attitude of students in higher vocational colleges has a positive and significant effect on their willingness to start a business.

$\mathrm{H} 2$ : The family support of students in higher vocational colleges has a positive and significant effect on their willingness to start a business.

H3: The perceived behavior control of students in higher vocational colleges has a positive and significant effect on the willingness to start a business.

\subsection{Overview of Research}

The research design was a five-step process that included: choosing methods to conduct the research, finding the participants, collecting data, analyzing data, and probing into countermeasures to strengthen students' willingness to run a new business. The data collection contained 313 vocational students and 100 of their parents, 100 teachers and 20 governors. Researchers sent out questionnaires to 20 higher vocational colleges and dispatched it to 313 students and there were 290 effective questionnaires were collected. To examine attitudes of teachers and parents toward the entrepreneurial of the students, we chose a narrative approach, with open-ended interviews as the main form of data collection. The author studies the present situation of students' entrepreneurship and the supporting polices of governors by using the interviews and documentation. And through analyzing the data in this way, the researcher was able to find the real entrepreneurial intentions that reflected the willingness of the higher vocational students to create enterprises, so that some meaningful suggestions would be proposed for cultivating the students to get more knowledge about self-employment and entrepreneurship.

\subsection{Research Questions}

Through reading and sorting out the existing literature and on-the-spot investigation, we can find the factors that affect the entrepreneurial willingness of students in higher vocational colleges in Sichuan Province can be divided into two aspects: subjective and objective aspects. Among them, 
objective factors include national, local and college policy guidelines, education from university and family etc. Subjective factors include students' individual characteristics, students' entrepreneurial attitude, students' entrepreneurial ability, etc. In order to facilitate the smooth progress of future research, Ajzen's planned behavior theory is used to study and analyze students' entrepreneurial willingness. In this study, on the basis of the planned behavior theory, the generation of higher vocational college students' entrepreneurial will is the result of the comprehensive effect of three variables: behavior attitude, subjective norms and perceived behavior control.

\section{Results}

The portrait of entrepreneurial orientation of vocational college students' willingness emerged through the depth interviews and inductive analysis process. This process included multiple perspectives, which involved the students, parents, teachers and governors. The data indicated a clear pattern that the students were very happy to have the opportunity to start a new business, and they were generally able to engage in a more active way to take advantage of the government policies. However, reflecting on the help of government policy seemed no significance to them. Our conclusions were:

Entrepreneurial attitude mainly reflects whether students' willingness to start a business is positive or negative, that is, the better the social environment, education and entrepreneurial atmosphere are, the more positive the students' mood towards starting a business and their behavior will be. On the contrary, if the students' mood is not high, then their behavior will be very negative. For higher vocational college students, their entrepreneurial attitude can reflect their interest in entrepreneurial behavior and whether such behavior has certain attraction to them or not will be affected by the differences in students' individual characteristics, such as values, career development expectations, etc.

Subjective norm is the social pressure that individuals perceive when considering whether to perform behaviors [8]. Whether higher vocational college students start their own businesses or not is influenced not only by individual characteristics, but also by the outside environment, for example, the views of "important groups" such as government policies, society views, colleges education, families support, relatives' influence, teachers and friends can have an impact on individual entrepreneurial behavior. The more these "important groups" support entrepreneurship, the stronger the students' willingness to start a business will be more possible to carry out their companies. Therefore, the attitude and public opinion of the other people around the students, as well as the policies and regulations of the government and colleges, will have an impact on students' entrepreneurial behavior.

Perceptual behavior control is the degree of self-control (a subjective perception of the ease of the behavior process) when individuals perform behaviors, and it is also the degree of difficulty that students perceive in performing entrepreneurial behaviors. When students have certain entrepreneurial ability, knowledge and resources, such as sufficient entrepreneurial capital and better entrepreneurial opportunities, then the willingness to start a business will be increased. After all, starting a business after graduation is not the only choice for higher vocational college students. In the process of starting a business, they are bound to face risks and setbacks. Whether they can endure the test and form good self-control and adjustment or not is related to students' knowledge, courage, ability, experience and characters.

Higher vocational colleges are a key link in cultivating entrepreneurial talents in the process of promoting the realization of the goal of an innovative country [9]. And they are also the key subjects participating in $\mathrm{Xi}$ Jinping's entrepreneurship education in the new era. Vigorously carrying out entrepreneurship education is of great significance to China's national construction, educational reform and high-quality development of higher vocational students in modern time [10]. Our research revealed that the critical dimension of entrepreneurial willingness of vocational college students' is not related with government policies, but the motivation of their interests and their diathesis, as well as the help of parents' support have greater impact on their creation of new career.

In order to summarize the entrepreneurial situation of the students in higher vocational colleges in Sichuan Province, objectively evaluate the current situation of students' entrepreneurship, rationally analyze the difficulties of students' entrepreneurship, and help students seek solutions. Besides, to further obtain real first-hand data for the studies, this paper takes higher vocational college students as the research object through random sampling survey. This paper describes the current situation and difficulties of higher vocational college students' entrepreneurship from their own situation, interest preference, and cognition and curriculum preference.

In the process of selecting research samples, 313 questionnaires were distributed to higher vocational college students from 20 colleges in Sichuan, and 290 complete valid questionnaires were actually recovered. The recovery rate of valid questionnaires reached $92.65 \%$ and the effective sample size reached 5 times of the number of measurement items, which met the requirements in sample integrity and effectiveness. The following is a basic description of the demographic characteristics of the student sample, as shown in Table 1.

Table 1. Descriptive Statistics of Demographic Characteristics of Student Samples.

\begin{tabular}{llll}
\hline Demographic variables & Variable Values & Frequency & Percentage \\
\hline Gender & Boys & 122 & $42.1 \%$ \\
& Girls & 168 & $57.9 \%$ \\
\hline
\end{tabular}

\subsection{Current Situation of Vocational College Students'Sense to Employment}

From daily observation and communication with the respondents involved in higher vocational colleges, it can be seen that most of the students have poor academic performance. Due to their insufficient performance, they choose to learn skills in higher vocational colleges so as to be able to survive in employment. Most of these higher vocational college students don't perform 
well in college. Their learning enthusiasm is not high and their learning attitude is not correct. Although there are not many students with high learning initiative, the vast majority of students are confused and do not know where to go in the future. They have no idea about future employment and career planning. Although both parents and teachers have made career planning guidance for them, their awareness, thoughts, expectation and preparation of starting a business are still insufficient.

\subsection{Interest Preference of Higher Vocational College Students in Entrepreneurship}

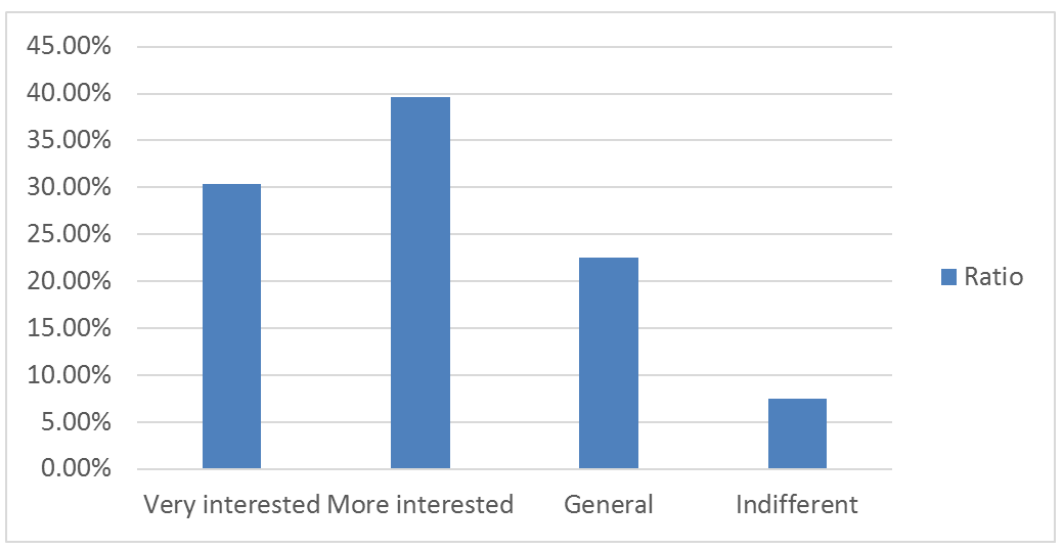

Figure 1. Students' Interest in Entrepreneurship.

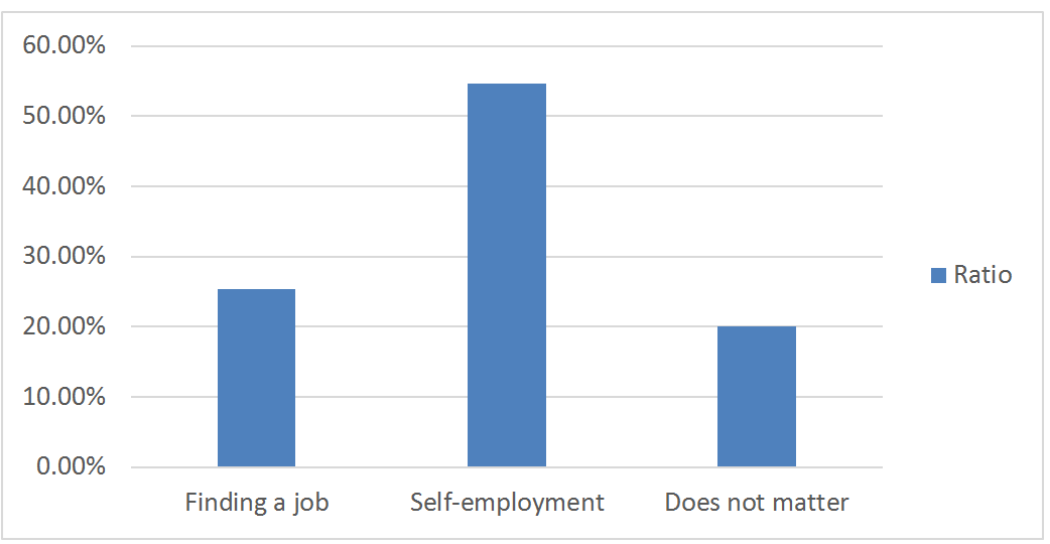

Figure 2. Respondents' Preference for Self-employment in Job Hunting.

From the above two figures, it can be clearly seen that the students in higher vocational colleges in Sichuan Province have a certain foundation in entrepreneurship. Students have certain curiosity and demand for entrepreneurship. According to Ausubel's motivation theory, we can try to change this motivation into students' entrepreneurship behavior through guidance. In terms of entrepreneurial practice, Figure 2 illustrates that after graduation and work, students' cognition of starting a business is relatively in a traditional way. For example, the investigation result shows students in several higher vocational colleges always get some business experience without any assistance from college education during their stay in college. Therefore, according to the students' cognition, there is no effective education on starting a business on campus, instead there is a lag on entrepreneurial interest training for students.

\subsection{Cognition of Higher Vocational College Students' Entrepreneurship}

In terms of entrepreneurial objectives, as it can be seen from
Figure 3, 49.51\% of the students believed that they have to find their own way out due to the fact that they could not find an ideal job; and 20.91\% thought they can "make more money" if they can create a company by themselves; only $20.62 \%$ thought the main goal of starting a business is to "display and test one's ability" and $8.96 \%$ don't know why they should have a try to run a company. These figures show that the purpose of students in higher vocational colleges is mainly focused on the entrepreneur ratio, instead of showing students' interest and their own abilities on creating a new business.

In terms of cognition of entrepreneurial barriers, it can be seen from Figure 4 which shows the proportions of capital, knowledge and ability are relatively balanced, such as $29.65 \%$ of capital, $21.49 \%$ of ability, $21.39 \%$ of knowledge and $21.47 \%$ of experience. This means that students' cognition of starting a business of the difficulties is relatively objective. Therefore, colleges should construct a multi-party comprehensive resource model to guide the students having a correct attitude to face these difficulties. 


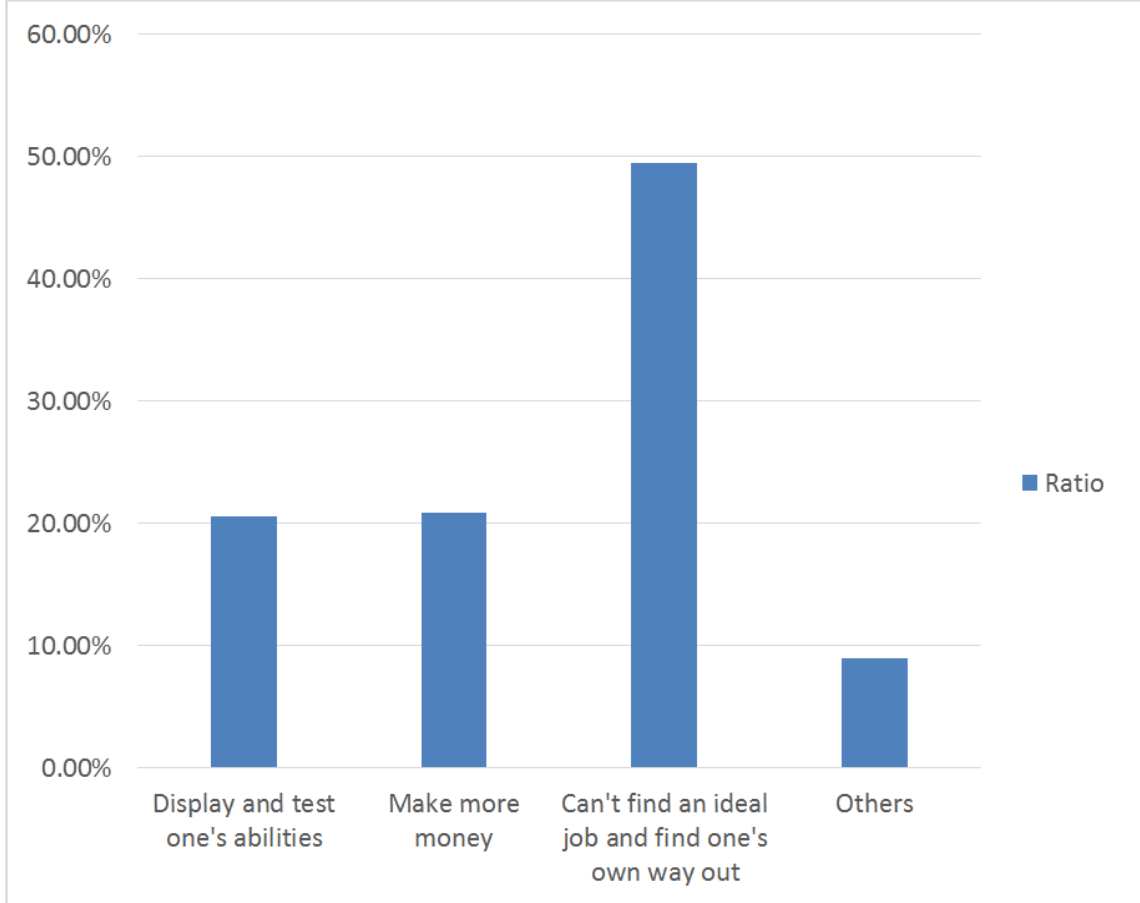

Figure 3. Students' Cognition of Entrepreneurial Purpose.

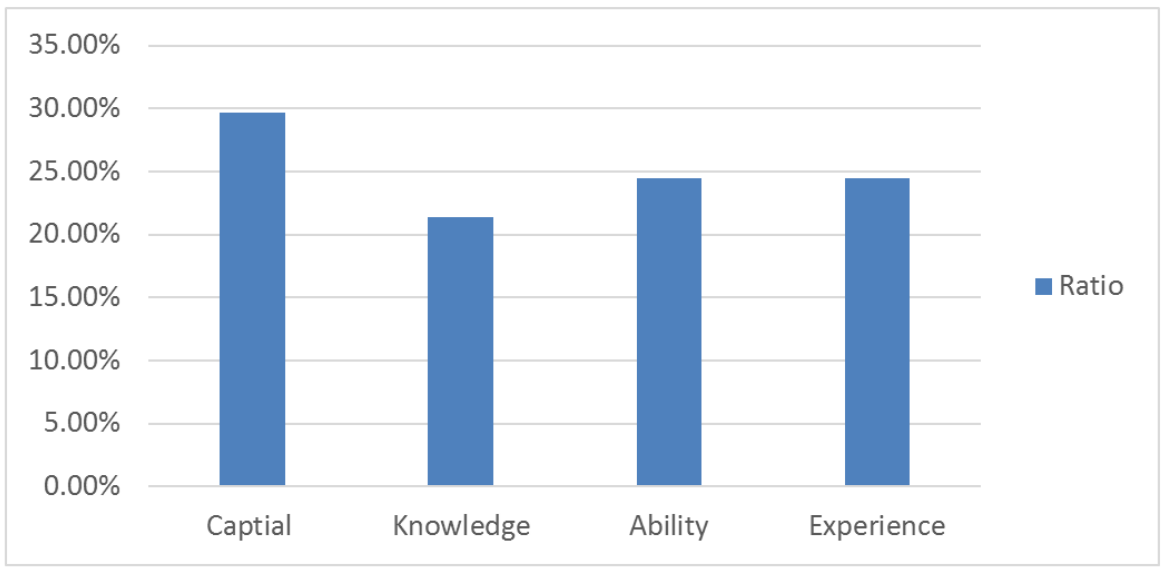

Figure 4. Students' Cognition of the Biggest Obstacle to Entrepreneurship.

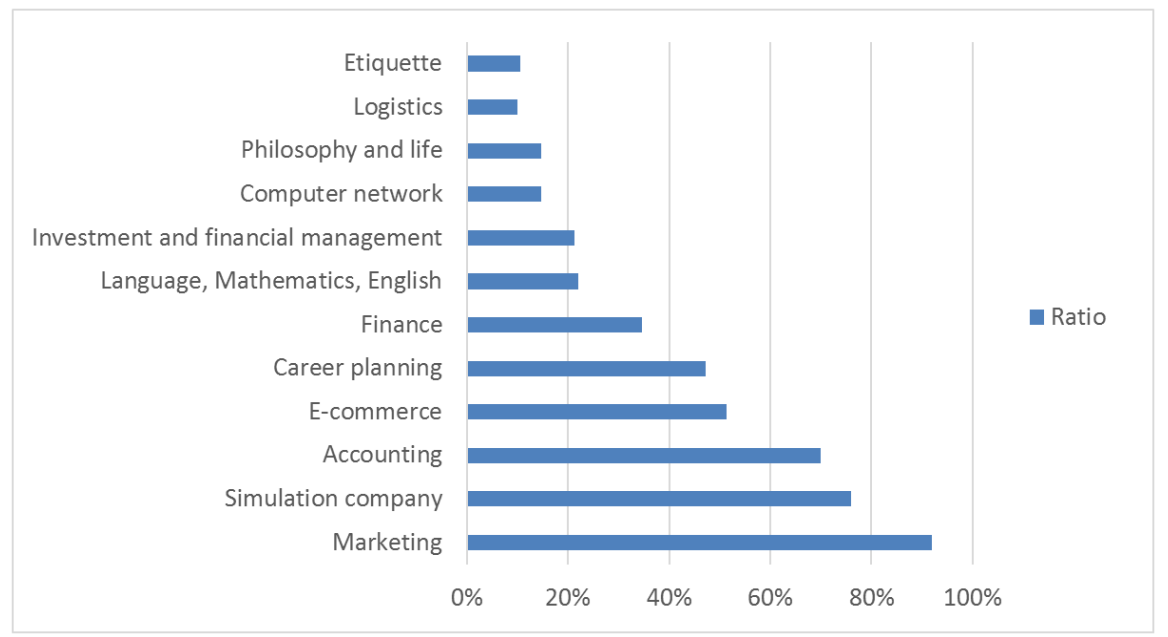

Figure 5. Students' Preference for Entrepreneurship Education Courses. 


\subsection{Preference for Entrepreneurship Education Curricula of Higher Vocational College Students}

Judging from the results of the survey, Figure 5 shows the vast majority of students are pragmatic, their preference for entrepreneurship teaching contents, or the ranking of courses in their mind are more helpful to train students' entrepreneurial skills. They prefer to choose courses like marketing, Simulation Company, accounting and e-commerce to get more knowledge about running a business, as well as the course of career planning also reflects the strong demand on company operations. Comparing the choices of students, it can be seen that students do not care about the course which has less relation on the company operation, such as language, mathematics, English, etiquette, philosophy and life etc.

\subsection{The Overall Situation and Difficulties of Higher Vocational College Students' Entrepreneurship}

According to the survey, the entrepreneurship of higher vocational college students in Sichuan Province reveals the phenomenon of "two low and one high". Firstly, students' attitude towards entrepreneurship is relatively high due to the rendering of the entrepreneurship environment from government and the increasingly prominent concept of entrepreneurship education. And there are more and more students will care about entrepreneurship and have a high willingness to start a business. Secondly, although the students have a high willingness to start a business, the proportion of students who really have entrepreneurial behaviour is very low which will fundamentally hinder and limit their attitude to build entrepreneurship. The study shows that higher vocational college students with strong entrepreneurial would have more possibility to carry out entrepreneurial behaviour. But in fact, there are very few students transform their will into specific innovative behaviour. Moreover, among the few higher vocational college students who have specific entrepreneurial behaviors, the proportion of successful entrepreneurship is extremely low. The data released by the Chinese Academy of Social Sciences, Zhejiang University, which has a strong atmosphere of entrepreneurship education, also verified that the success rate of our students' entrepreneurship is extremely low, it has a success rate of $5 \%$ [11].

Exploring its causes about the phenomenon, it mainly reflects the following three aspects. Firstly, students refused to

set up a new company because of the inadequate resources, such as the lack of entrepreneurial opportunities and a good entrepreneurial environment. Although some higher vocational college students choose to start a business, they are not willing to do it by themselves, for they cannot find a good job. Nowadays, the society is changing rapidly, there are unlimited possibilities and demands behind the changes in industrial structure, consumption structure, population structure and policies and regulations, students should have keen eyes and horizons so as to explore and utilize these opportunities to keep up with these change. However, higher vocational college students are badly short of the ability to cope with these matters when they face these challenges. Hence, they choose to start their own businesses as the second best choice, and their entrepreneurial effect is not ideal. The second reason is the inadequate entrepreneurial resources made them encounter many difficulties. Inevitably, insufficient funding acts as the biggest obstacle for setting up the new business from the view of higher vocational college students, because the venture capital mainly comes from family support. But the level of entrepreneurial resource is uneven in different region with different culture and economic level. In addition, technical resources, network resources and market resources are also important resources for students to start their own businesses. Finally, the survey shows that the existing entrepreneurship education cannot fully meet the needs and development of students. Students study in a relatively closed learning environment for a long time, and there are fewer opportunities for them to communicate with the public, which is useless for an assistance to improve their entrepreneurship ability. And different performances of the students in entrepreneurship education indicate their knowledge span is quite different. Excellent entrepreneurs need to have excellent comprehensive quality, but at present, students of different majors do not know too much knowledge about other fields, thus causing the shortage of students' entrepreneurship ability.

Generally speaking, the current entrepreneurial willingness of students in higher vocational colleges in Sichuan Province is more positive, which shows that perceptual cognition is obviously stronger than rational cognition. Although they have strong entrepreneurial will, they lack a rational view of the relationship between employment and entrepreneurship. At the same time, we have noticed that entrepreneurship education and the environment still need to be improved.

\section{Analysis of Influencing Factors Model of Entrepreneurial Intention}

\subsection{Variable Definition and Measurement}

The conceptual model of this paper explains the influence of three latent variables on the willingness of Sichuan higher vocational college students to participate in entrepreneurship: entrepreneurial behavior attitude, entrepreneurial subjective norms and entrepreneurial perceived behavior control. And the four potential variables of entrepreneurial behavior willingness are interpreted as the following tables from Table 2 to Table 5 .

\subsection{Reliability and Validity Test}

In this paper, the independent variables and dependent variables of the measurement scale are analyzed by SPSS 22 software. The KMO value of the sample is 0.811 , which indicates that the sample data is good. Bartlett's sphericity 
test results show that the chi-square value of the sample data is $1981.24(p=0.000)$ at 105 degrees of freedom, which indicates that the sample data is suitable for EFA test. After rotation, the measurement items with factor load greater than 0.5 are retained. Then the classical analysis method is used to carry out confirmatory factor analysis on the sample data to detect the reliability and validity of the sample data. Using
AMOS24 software to analyze the sample data, the overall fitting index of CFA model is $140.589(\mathrm{df}=82), \mathrm{p}=0$. 000 . Among the fitting indexes, the test results $\mathrm{X}^{2} / \mathrm{df}=1$. 171, $\mathrm{GFI}=0.939, \mathrm{CFI}=0.969, \mathrm{TLI}=0.961, \mathrm{IFI}=0.970, \mathrm{RMSEA}=0$. 050, RMR $=0$. 058. The comparison and judgment standards show that the overall fitting effect of the model is better. As shown in Table 6.

Table 2. Subjective Standard Measurement Items for Entrepreneurship.

\begin{tabular}{lll}
\hline Coding & Measurement Item & Source of Item \\
\hline 1 & The government has perfect preferential policies for starting businesses. \\
2 & The college has a mature start-up base and teachers. \\
3 & Relatives and friends can understand and support my choice of starting a business. \\
4 & My family will fully understand and support my choice to start a business. \\
5 & If I choose to start a business, I can get the approval of my teachers and classmates. \\
6 & If I choose to start a business, I can get the approval of the public. \\
7 & The successful business cases reported by the media will inspire me to start a business. \\
\hline
\end{tabular}

Table 3. Measurement Items of Entrepreneurial Behavior Attitude.

\begin{tabular}{lll}
\hline Coding & Measurement Item & Source of Item \\
\hline 1 & I started my business to survive. & \\
2 & I can make myself feel successful when I start a business. & Xiong Zhiwei and Wang Zhengbing [4] \\
3 & It can bring me a lot of wealth when I start a business. & Yu Liwei [13] \\
4 & It is my hobby to start a business. & \\
\hline
\end{tabular}

Table 4. Measurement Items of Entrepreneurial Perception Behavior Control.

\begin{tabular}{|c|c|c|}
\hline Coding & Measurement Item & Source of Item \\
\hline 1 & I like to take risks and challenge myself. & \\
\hline 2 & I have certain professional skills needed to start a business. & \\
\hline 3 & I have some practical experience in starting a business & Xiong Zhiwei and Wang Zhengbing \\
\hline 4 & I have a strong ability to recognize opportunities. & (2012); Zhu Yongyue and Ouyang \\
\hline 5 & I have the social resources needed to start a business. & Chenhui (2017) \\
\hline 6 & I can constantly learn the knowledge of entrepreneurship technology training. & \\
\hline
\end{tabular}

Table 5. Measurement Items of Entrepreneurial Behavior Willingness.

\begin{tabular}{lll}
\hline Coding & Measurement Item & Source of Item \\
\hline 1 & I once thought about starting a business after graduation. & \\
2 & I am actively prepared to start a business. & Liu Jiafeng (2017) \\
3 & If conditions permit, I am very willing to start a business. & \\
\hline
\end{tabular}

Table 6. Overall Fitting Index Table of Conceptual Model.

\begin{tabular}{lllllll}
\hline Indicators & $\mathbf{X}^{\mathbf{2}} / \mathbf{d f}$ & GFI & CFI & TLI & IFI & RMSEA \\
\hline Evaluation criteria & $<3$ & $>0.900$ & $>0.900$ & $>0.900$ & $>0.900$ & $<0.080$ \\
Inspection Results & 1.717 & .939 & .969 & .961 & .970 & .050 \\
\hline
\end{tabular}

Secondly, further check the reliability and convergence validity of sample data measurement (as shown in Tables 1-7). The results show that the constructive reliability of all latent variables is higher than 0.70 , indicating that the sample data measurement has good reliability. In addition, the normalized factor load (Std.) point estimation values of each observation variable used to measure the item and the corresponding latent variable are significant at the confidence level that their $Z$ value $p$ is less than 0.001 , SMC values are greater than 0.3 , and the average variance extraction amount of each latent variable is higher than 0.50 , indicating that the sample data measurement has good convergence validity.

Table 7. Reliability and Convergence Validity Table.

\begin{tabular}{|c|c|c|c|c|c|c|c|c|c|}
\hline Variable & - & Parameter checki & & & & & $\begin{array}{l}\text { Item } \\
\text { reliability }\end{array}$ & $\begin{array}{l}\text { Composition } \\
\text { al reliability }\end{array}$ & $\begin{array}{l}\text { Convergence } \\
\text { validity }\end{array}$ \\
\hline- & - & $\begin{array}{l}\text { Non-normalized } \\
\text { coefficient }\end{array}$ & $\begin{array}{l}\text { Standard } \\
\text { error }\end{array}$ & $\mathbf{Z}$ value & $\mathbf{P P}$ & $\begin{array}{l}\text { Normalization } \\
\text { coefficient }\end{array}$ & SMC & CR & AVE \\
\hline $\mathrm{BA}$ & BA1 & 1.000 & - & - & - & .804 & .646 & .812 & .524 \\
\hline- & BA2 & 1.051 & .120 & 8.754 & $* * *$ & .798 & .637 & - & - \\
\hline- & BA3 & 1.358 & .161 & 8.432 & $* * *$ & .720 & .518 & - & - \\
\hline- & BA4 & 1.123 & .141 & 7.970 & $* * *$ & .542 & .304 & - & - \\
\hline
\end{tabular}




\begin{tabular}{|c|c|c|c|c|c|c|c|c|c|}
\hline Variable & - & Parameter check & & & & & $\begin{array}{l}\text { Item } \\
\text { reliability }\end{array}$ & $\begin{array}{l}\text { Composition } \\
\text { al reliability }\end{array}$ & $\begin{array}{l}\text { Convergence } \\
\text { validity }\end{array}$ \\
\hline- & - & $\begin{array}{l}\text { Non-normalized } \\
\text { coefficient }\end{array}$ & $\begin{array}{l}\begin{array}{l}\text { Standard } \\
\text { error }\end{array} \\
\end{array}$ & $Z$ value & $\mathbf{P P}$ & $\begin{array}{l}\text { Normalization } \\
\text { coefficient }\end{array}$ & SMC & CR & AVE \\
\hline BI & BI1 & 1.000 & - & - & - & .876 & .767 & .903 & .758 \\
\hline- & BI2 & 1.057 & .049 & 21.524 & $* * *$ & .956 & .914 & - & - \\
\hline- & $\mathrm{BI} 3$ & .873 & .053 & 16.351 & $* * *$ & .770 & .593 & - & - \\
\hline PBC & PBC1 & 1.000 & - & - & - & .792 & .627 & .848 & .583 \\
\hline- & $\mathrm{PBC} 2$ & .830 & .072 & 11.486 & $* * *$ & .689 & .475 & - & - \\
\hline- & $\mathrm{PBC} 3$ & 1.039 & .078 & 13.395 & $* * *$ & .803 & .645 & - & - \\
\hline - & PBC4 & .900 & .070 & 12.836 & $* * *$ & .765 & .585 & - & - \\
\hline $\mathrm{SN}$ & SN1 & 1.000 & - & - & - & .644 & .415 & .807 & .512 \\
\hline- & SN2 & 1.152 & .123 & 9.352 & $* * *$ & .689 & .475 & - & - \\
\hline- & SN3 & 1.118 & .113 & 9.936 & $* * *$ & .746 & .557 & - & - \\
\hline- & SN4 & 1.224 & .121 & 10.090 & $* * *$ & .776 & .602 & - & - \\
\hline
\end{tabular}

Note: BA (entrepreneurial behavior attitude,) BW (entrepreneurial behavior will), PBC (entrepreneurial perceived behavior control) SN (subjective norm of entrepreneurial behavior); $* * * \mathrm{p}<0.001, * * \mathrm{p} \leq 0.01, * \mathrm{p} \leq 0.05$.

\subsection{Research Hypothesis Testing}

Finally, AMOS24 software is used to analyze the sample data, and the path analysis index of conceptual model is obtained from the output results. As shown in Table 7. The result of path analysis of conceptual model shows that, the influence path coefficient of entrepreneurial behavior attitude to entrepreneurial behavior willingness is $0.311(\mathrm{p}<0.01)$, the influence path coefficient of entrepreneurial behavior subjective norm to entrepreneurial behavior willingness is $0.231(\mathrm{P}<0.01)$, and the influence path coefficient of entrepreneurial perceived behavior control to entrepreneurial behavior willingness is $0.421(\mathrm{P}<0.01)$. The original hypotheses $\mathrm{H} 1, \mathrm{H} 2$ and $\mathrm{H} 3$ are all supported by empirical data.

Table 8. Conceptual Model Path Analysis Results Table.

\begin{tabular}{|c|c|c|c|c|c|c|}
\hline Research Hypothetical Path & & & $\begin{array}{l}\text { In the meantime, } \\
\text { it is necessary to }\end{array}$ & $\begin{array}{l}\text { Standard } \\
\text { error }\end{array}$ & $\mathbf{P}$ & $\begin{array}{l}\text { Hypothetical } \\
\text { results }\end{array}$ \\
\hline $\begin{array}{l}\text { Entrepreneurial behavior } \\
\text { Attitude }\end{array}$ & $\rightarrow$ In the meantime, it is necessary to & $\begin{array}{l}\text { Willingness of } \\
\text { entrepreneurial behavior }\end{array}$ & .311 & .110 & .005 & Accept \\
\hline $\begin{array}{l}\text { Entrepreneurial behavior } \\
\text { Subjective norm }\end{array}$ & $\rightarrow$ In the meantime, it is necessary to & $\begin{array}{l}\text { Willingness of } \\
\text { entrepreneurial behavior }\end{array}$ & .231 & .130 & .003 & Accept \\
\hline $\begin{array}{l}\text { Perception of entrepreneurship } \\
\text { Behavior control }\end{array}$ & $\rightarrow$ In the meantime, it is necessary to & $\begin{array}{l}\text { Willingness of } \\
\text { entrepreneurial behavior }\end{array}$ & .421 & .164 & .002 & Accept \\
\hline
\end{tabular}

To sum up, the results show that the entrepreneurial attitude, family support and perceived behavior control of students in higher vocational colleges have a significant positive impact on entrepreneurial behavior willingness and the perceptual behavior control is the factor with the highest degree of influence. This finding is consistent with Liu Jiafeng's conclusion of empirical research on Changzhou college students' entrepreneurial willingness by using structural equation model. This conclusion shows that students at higher vocational college have a better self-awareness of entrepreneurship. They also realize that the constraints of objective conditions will be considered when they decide to set up a new business. Therefore, it requires the government to provide support for entrepreneurs in top-level system design. Meanwhile, it also requires that the entrepreneurship education in colleges should enhance students' self-realization satisfaction in entrepreneurship and make their own entrepreneurship ability match with the external entrepreneurship environment, so as to promote students to form positive entrepreneurial behavior attitude, family support and perceived behavior control from various aspects.

\section{Countermeasures and Suggestions on Entrepreneurial Willingness}

\subsection{The Government Needs to Perfect Top-Level System Design}

At present, the policies of various departments and social organizations in Sichuan Province on entrepreneurship education for higher vocational students are mainly based on the relevant measures put forward on the basis of the guiding opinions of the State Council, and there are no specific operating rules, resulting in the lack of theoretical guidance for the implementation of the policies. Therefore, Sichuan City should provide guidance documents for entrepreneurship education in higher vocational colleges to assist higher vocational college students to start their own businesses. They'd better to issue corresponding supporting policies to form a relatively perfect top-level system and enhance the execution and confidence of the local government and colleges. All departments at all levels in Sichuan Province should give full play to their functions, pay attention to and 
support the promotion of entrepreneurship education in higher vocational colleges at all levels, and mobilize society and enterprises to provide resources for higher vocational college students to start their own businesses. On this basis, relevant departments of the local government conduct more comprehensive and sufficient investigations into higher vocational colleges. Each region provides preferential policies for higher vocational college students to start their own businesses according to their actual situation, and ensures equal opportunities for students to start their own business. In the process of policy implementation, balance and coordinate the contradiction between the government and the college through the committee. In view of the relevant issues of higher vocational college students' entrepreneurship, this paper puts forward clear regulations to guide the college's operation details and procedures, it establishes a corresponding accountability system to ensure that higher vocational college students' entrepreneurial wishes and behaviors are treated fairly and justly, so as to mobilize the entrepreneurial enthusiasm of higher vocational college students.

Entrepreneurial behavior is deeply affected by many factors and is full of various risks. The government is the main body for the development and guarantee of higher vocational college students' entrepreneurship. It should not only strengthen and perfect relevant system measures, but also provide guidance and help for the entrepreneurship process, so as to promote the quality of entrepreneurship and provide better guarantee for the development of enterprises. First of all, the high-tech parks, business incubators, science parks in higher vocational colleges and university science parks set up by the government can all provide students with necessary places to start their own businesses. The government can give rent relief or preferential treatment to reduce the financial burden of enterprises in the initial stage of starting their own businesses, thus it can provide students with more practical platforms with better quality. Secondly, higher vocational colleges can try to set up special support funds to assist enterprises in the early stage of starting a business to apply for a variety of special support funds, which sets up at the national, provincial, ministerial and municipal levels, and use effective policies and measures to inspire and encourage relevant financial departments to provide financial support for promising start-up projects, while giving discount interest concessions within their capabilities. Thirdly, government departments should also provide tax concessions or other relief measures for enterprises and individuals on the basis of rational research, so as to reduce the tax burden of enterprises.

\subsection{Raise the Attention of Colleges to Entrepreneurship Education}

At present, China is in a new era. In the process of building an innovative country, the demand for manpower support and talent reserve has prompted a large demand for innovative talents. As an important subject in the field of vocational education, higher vocational colleges are the main output positions and bases for the cultivation and education of innovative talents, they should take the initiative to conform to the development requirements of the new era and contribute key forces to the construction of an innovative country. In view of the obstacles and difficulties in the training of financial and commercial entrepreneurship talents in higher vocational colleges in Sichuan Province, we should continue to conduct in-depth investigations to promote educational reform. In addition, recommend entrepreneurship education and make entrepreneurship education undertake its due value, purpose and mission through designing some systems and methods conducive.

\section{Conclusion}

Through the investigation of higher vocational college students and students majoring in finance and commerce in Sichuan higher vocational colleges, we know that entrepreneurship is regarded by vocational education students as a forced choice to relieve employment pressure, but they are glad to have the opportunity to start their own business, and their entrepreneurial willingness, in other words, their autonomy of entrepreneurship is the most important factor that can influence their intentions to entrepreneurship. From the research results, we can see that students have certain curiosity and demand for entrepreneurship, they also have active attitude and willingness towards entrepreneurship, but they rarely take action and their chances of success are slim, this is due to their lack of entrepreneurial opportunities, environment, resources and abilities. Besides, the behavior attitude, family support, perceived behavior control are proved to have a positive and significant effect on students' entrepreneurial behavior willingness. What's more, students' self-awareness of entrepreneurship will be encouraged by objective conditions. Therefore, to encourage vocational education students to actively start their own businesses, the government and the college should take various measures to create a good entrepreneurial environment and provide good policy support.

\section{Acknowledgements}

This project was sponsored by China Scholarship Council \&Humanities and Social Sciences Planning Fund Project of the Ministry of Education of the People's Republic of China (\#18YJA880002).

\section{References}

[1] Eric Morath,"April Jobs Report Likey to Show Highest Unemployment Rate on Record”, May 3, 2020, Wall Street Journal,

https://www.wsj.com/articles/April-jobs-report-likely-to-show -highest-unemployment-rate-on-record-11588514401.

[2] Liu Jiafeng. An Analysis of the influence of entrepreneurship education based on Planned Behavior Theory on college students' entrepreneurial intention [J]. Higher Education Exploration, 2017 (5): 117-122. 
[3] Nielsen, S. L. \& Storvang, P. (2015) DesUni: university entrepreneurship education through design thinking in Education + Training. Vol. 57 Iss 8/9 pp. 977-991

[4] Mo Huan. A path map of entrepreneurial intention in Chinese contex-Based on the theory of planed behavior [J]. Science Research Management, 2009, 30 (06): 128-135.

[5] Rauch, A., Wiklund, J., Lumpkin, G. T. \& Frese, M. (2009). Entrepreneurial Orientation and Business Performance: An Assessment of Past Research and Suggestions for 143" the Future. Entrepreneurship Theory and Practice, 33: 761-787. doi: $10.1111 /$ j.1540-6520.2009.00308.x.

[6] Bridging Disciplines Program (BDP). (2016). Innovation; Creativity and Entrepreneurship. Austin: University of Texas. Retrieved from: https://www.utexas.edu/ugs/bdp/program. Last retrieved from 2017 Jul 19.

[7] Chen Shaoxia, Zhang Depeng. Formation mechanism of customer innovation value and construction of its econometric model: Based on the theory of Planned Behavior [J]. Science \& Technology Progress and Policy, 2014, 31 (20): 18-26.

[8] J. C. Anderson, D. W. Gerbing. Structural Equation Modeling in Practice: A Review and Recommended Two-Step Approach [J]. Psychological Bulletin, 1988, 103 (3): 411-423.
[9] Double Gist. (2017), Adolescent Problems and their Counselling Strategies in Enugu State. Available from: $\mathrm{http}: / /$ www.doublegist.com/adolescentproblems-counseling-str ategies-enugu-state. [Last accessed on 2017Oct 05].

[10] Li, H. F. (2010). College students' entrepreneurship education research in China - entrepreneurship education by the ministry of education pilot colleges and Lanzhou University as an example. Journal of Lanzhou University. Lan Zhou.

[11] Chen xiangfen. Research on collaborative innovation talent training mode in higher vocational colleges under the background of One Belt And One Road [J]. China vocational and technical education, 2016 (4): 42-45.

[12] Zhu Yongyue. Multivariate Data Analysis [M]. China Machine Press, 2017.

[13] J. F. Hair, W. C. Black, B. J. Babin, R. E. Anderson Bridging Disciplines Program (BDP). (2016). Innovation; Creativity and Entrepreneurship. Austin: University of Texas. Retrieved from: https://www.utexas.edu/ugs/bdp/program. Last retrieved from 2017 Jul 19. 